\title{
Influence of Slow Release Nitrogenous Fertilizers on Soil Enzyme Activity and Microbial Population under Laboratory Condition
}

\author{
Priyanka B. Patil", A.D. Kadlag and A.G. Durgude \\ Department of Soil Science and Agricultural Chemistry, College of Agriculture, Mahatma \\ Phule Krishi Vidyapeeth, Rahuri, (M.S), India \\ *Corresponding author
}

\section{A B S T R A C T}

\section{Keywords}

Slow release nitrogenous fertilizers, Urease, Dehydrogenase activity, Bacterial population

\section{Article Info}

Accepted:

07 June 2019

Available Online:

10 July 2019
An Incubation study under laboratory condition were conducted during 2015-16 with a view to study "Influence of slow release nitrogenous fertilizers on soil enzyme activity and microbial population under laboratory condition" The laboratory incubation experiment was conducted in completely randomized design. In incubation study, the urease enzyme activity was increased with an increased period of incubation in all the treatments. Dehydrogenase enzyme activity was significantly higher in treatment GRDF at 7, 21, 45 and 90 DAA $\left(1.41,1.55,1.69\right.$ and $1.56 \mu \mathrm{g} \mathrm{TPF} \mathrm{g}^{-1}$ soil $\mathrm{hr}^{-1}$ respectively). It was increased upto 45 DAA and decreased at 90 DAA. The treatment GRDF significantly recorded the higher population of Nitrosomonas at all the period of incubation and on par with treatment RDN-SCU, NCU and CDU at 7 and 14 DAA. The use of NCU and SCU recorded less Nitrobacter population in early period of incubation. The application of nitrogen through slow release fertilizers as CDU, NCU and SCU and their combination with urea and among the organic sources release the soil available nitrogen with advanced incubation period. It was decreased in treatment GRDF and RDN-CDU at 90 DAA. The release of ammonical nitrogen in all the treatments showed the similar trend to that of soil available nitrogen at all the period of incubation. The slow release nitrogen fertilizer treatment @ $50 \%$ RDN-urea + $50 \%$ RDN either through CDU, NCU or SCU were beneficial for release of nitrate nitrogen in soil.

\section{Introduction}

The slow release fertilizers are slow acting and facilitate long term availability of the nutrients often synchronized with the physiological need of plants and are considered as one of the most viable alternative for the sustainable plant productivity (Dahiya et al., 2004). All the transformation of nutrients occurring in soils is stimulated by the enzymes that convert into forms available to plants and microorganisms. Enzymes are frequently referred to as markers of soil environment purity (Aon and Colaneri, 2001). The biological component of soils usually responds more rapidly to changing soil conditions than either the chemical or physical properties. Soil enzymatic activities have been used as indicators of soil fertility because they are a 
reflection of the effects of cultivation, soil properties and pedological amendments (Chang et al., 2007).

Soil urease is one of the most active hydrolytic enzyme in the soil, the hydrolysis of urea which was applied in to soil by urease release ammonia that can be used by crops, play an important role in $\mathrm{N}$ cycle. Soil urease is given more attention because it can be used as important index to evaluate soil organic matter (SOM) and $\mathrm{N}$-applied and more quickly response to environment change and agricultural management (Sun et al., 2015).

Dehydrogenases are considered to play an essential role in the initial stages of the oxidation of soil organic matter (Ross, 1971) by transferring hydrogen and electrons from substrates to acceptors. Many different intracellular enzymes or enzyme systems contribute to the total soil dehydrogenases activity.

The nitrogen requirements of all the field crops are comparatively higher than the other nutrients like phosphorus, potassium, sulphur etc. However, the use efficiency of applied nitrogen through fertilizers are less because of hydrolysis of nitrogen fertilizer and their transformation by means of soil chemical reactions in soil or by microbial activity within short span of time. This might be mismatched with nitrogen requirement of crop as per their crop growth stage. The unutilized nitrogen by the crop leads to losses either through leaching or volatilization process. This is the main threat in less use efficiency of nitrogen added through chemical fertilizers. To overcome these constrain in increasing the use efficiency of nitrogen in soil the present investigation was planned. An incubation study of periodical release of nitrogen through slow release nitrogen fertilizers under controlled condition on Inceptisol soils was studied.

\section{Materials and Methods}

An incubation study was conducted in the laboratory under ambient conditions for 90 days. The soils from the STCRC field was collected and processed in the laboratory. The processed soil was saturated with deionized water and allowed to evaporate to attain the field capacity moisture by gravimetric method. The known quantity of soil at field capacity moisture and quantity of slow release nitrogen fertilizer were mixed with soil as per treatment. The treatment consists of control, GRDF, $100 \%$ recommended dose of nitrogen through crotonylidene diurea (CDU), neem coated urea (NCU) and sulphur coated urea (SCU). 50\% recommended dose of nitrogen through urea plus remaining 50\% RDN either through NCU, CDU and SCU, 50:50\% combination of slow release nitrogen fertilizers. The recommended dose of $\mathrm{P}_{2} \mathrm{O}_{5} 60$ $\mathrm{kg} \mathrm{ha}^{-1}, \mathrm{~K}_{2} \mathrm{O} 40 \mathrm{~kg} \mathrm{ha}^{-1}$ and $10 \mathrm{t} \mathrm{ha}^{-1} \mathrm{FYM}$ were applied uniformly to all the treatments. These treatments were applied for $2 \mathrm{~kg}$ processed sieved soil filled in plastic bowl. These treated soils were filled in plastic bottles in triplicate separately for each incubation period. These bottles were kept in laboratory under ambient condition and maintained their moisture to field capacity by gravimetrically. The soils of these bottles were analyzed for enzyme activity viz., urease, dehydrogenase, Nitrosomonas and Nitrobacter count and also for soil available nitrogen, $\mathrm{NH}_{4}{ }^{+-} \mathrm{N}$ and $\mathrm{NO}_{3}{ }^{-} \mathrm{N}$ as per incubation period by destructive methods.

\section{Analysis of soil enzymes}

Urease activity was assessed as the rate of urea hydrolysis in the soil samples by determining the urea remaining (unhydrolysed) at different days of incubation following the method of Tabatabai and Bremner (1969) Dehydrogenase was estimated as described by Casida et al., (1964). 
Nitrosomonas and Nitrobacter count by using Stephonson's medium, serial dilution and plating technique method proposed by Halvorsun and Zeiglar (1993). All the experimental data of soil, soil microorganism were statistically analyzed to draw conclusion of significance by using the methods prescribed by Panse and Sukhatme (1967) (Table 1 and 2).

\section{Results and Discussion}

Effect of slow release nitrogenous fertilizer on soil enzyme activity in incubation study

\section{Urease enzyme activity amidohydrolase EC 3.5.1.5)}

(Urea

The periodical soil urease enzyme activity as influenced by the various treatment of slow release nitrogenous fertilizers are reported in table 3 and Figure 1. The urease enzyme activity in soil was significantly influenced by the treatment of slow release nitrogenous fertilizers at 7, 21, 45 and 90 DAA over the initial soil urease enzyme activity $(16.30 \mu \mathrm{g}$ $\mathrm{NH}_{4}-\mathrm{N} \mathrm{g}^{-1}$ soil $\mathrm{h}^{-1}$ ). The urease enzyme activity was increased with an increased period of incubation in all the treatments. The highest urease enzyme activity was observed in treatment general recommended dose of fertilizer (GRDF) at 7, 21, 45 and 90 DAA $\left(32.73,34.83,37.89\right.$ and $35.79 \mu \mathrm{g} \mathrm{NH}_{4}-\mathrm{N} \mathrm{g}^{-1}$ $\mathrm{h}^{-1}$ respectively). This might be because of in treatment GRDF, the nitrogen applied through the urea fertilizer was readily available to urease enzyme as substrate and there was faster conversion of amide nitrogen to ammonical $\left(\mathrm{NH}_{4}-\mathrm{N}\right)$ and nitrate nitrogen $\left(\mathrm{NO}_{3}{ }^{-} \mathrm{N}\right)$. However, at 90 DAA the urease enzyme activity was decreased in treatment GRDF (35.79 $\mu \mathrm{g} \mathrm{NH}_{4}-\mathrm{N} \mathrm{g}^{-1}$ soil $\mathrm{h}^{-1}$ ). The decrease in urease enzyme activity indicated that application of chemical fertilizer as urea to provide the nitrogen was released the nitrogen upto 45 DAA and later on it was decreased. This type of release of nitrogen through chemical fertilizer may not provide the nitrogen at later growth stages of crop growth. Similar, results was also reported by Kissel et al., (2008) and Pascual et al., (2002).

The application of nitrogen solely through crotonylidene diurea (CDU), neem coated urea (NCU), sulphur coated urea (SCU) and their afforestation of nitrogen as $50 \% \mathrm{~N}-\mathrm{RDF}$ and remaining 50\% RDN either through CDU, NCU or SCU were recorded less activity of urease enzyme in soil at 7, 21, 45 and 90 DAA respectively as compared to GRDF. The treatment $50 \%$ RDN-urea+ $50 \quad \mathrm{~N}-\mathrm{NCU}$ recorded significantly the higher urease enzyme activity at $7 \mathrm{DAA}\left(30.98 \mu \mathrm{g} \mathrm{NH}_{4}-\mathrm{N} \mathrm{g}^{-}\right.$ ${ }^{1} \mathrm{~h}^{-1}$ ) over rest of the treatments. Similar treatment recorded higher values of urease enzyme at 21,45 and 90 DAA $(32.38,33.34$ and $34.21 \mu \mathrm{g} \mathrm{NH} \mathrm{NH} \mathrm{g}^{-1}$ soil h${ }^{-1}$ respectively). However, it was statistically on par with $50 \%$ RDN-urea $+50 \% \mathrm{~N}-\mathrm{CDU}$ at 21 DAA (31.59 $\mu \mathrm{g} \mathrm{NH}_{4}-\mathrm{N} \mathrm{g}^{-1}$ soil $\mathrm{h}^{-1}$ ) and at $45 \mathrm{DAA}$ with treatment 50\% RDN-urea $+50 \% \mathrm{~N}-\mathrm{CDU}$ and $50 \%$ RDN-urea $+50 \% \mathrm{~N}-\mathrm{SCU}$ (32.64 and $32.46 \mu \mathrm{g} \mathrm{NH}_{4}-\mathrm{N} \mathrm{g}^{-1}$ soil $\mathrm{h}^{-1}$ ) and at $90 \mathrm{DAA}$ (33.25 and $32.55 \mu \mathrm{g} \mathrm{NH}_{4}-\mathrm{N} \mathrm{g}^{-1}$ soil $\mathrm{h}^{-1}$ ) respectively. These results revealed that the application of nitrogen through 50\% RDNurea fertilizer and $50 \% \mathrm{~N}$ through either CDU, NCU or SCU were beneficial for slowly releasing the nitrogen in soil up to 90 days after application. The addition of nitrogen through NCU, CDU and sulphur coated nitrogen inhibit the processes of releasing the nitrogen in soil through chemical reactions or microbial processes in early days after their application and slowly release with an advanced period of incubation. These results are in accordance with the results of Singhal and Mudgal (1983). The slow release of nitrogen applied through the slow release fertilizer as sole or in combinations in the ratio of 1:1 released the nitrogen slowly to longer period. This might be because of nitrogen 
applied through slow release fertilizers are in the organic form and it has to transformed into inorganic form as $\mathrm{NH}_{4}{ }^{+}-\mathrm{N}$ or $\mathrm{NO}_{3}{ }^{-}-\mathrm{N}$ for their availability to the crops. This process is mainly governed by the urease enzyme and microbial process which was slower than the chemical reactions governed in soil.

Dehydrogenase enzyme activity $((S)$-malate: $N A D P+$ oxidoreductase (decarbooxylating) (EC 1.1.1.3))

The soil dehydrogenase enzyme activity is one of the important soil characteristics to decide the quality of soil. The activity of dehydrogenase indicated the availability of nitrogen and microbial population. In view of this the soil dehydrogenase enzyme activity was assessed periodically in an incubation study with the addition of slow release nitrogenous fertilizers (Table 4 and Figure 2).

The use of slow release nitrogenous fertilizer significantly influenced the soil dehydrogenase enzyme activity periodically under ambient condition. It was significantly higher in treatment GRDF at 7, 21, 45 and 90 DAA $\left(1.41,1.55,1.69\right.$ and $1.56 \mu \mathrm{g}$ TPF $\mathrm{g}^{-1}$ soil $\mathrm{h}^{-1}$ respectively). It was increased up to 45 DAA $\left(1.69 \mu \mathrm{g} \mathrm{TPF}^{-1}\right.$ soil $\left.^{-1}\right)$ and decreased at 90 DAA $\left(1.56 \mu \mathrm{g}\right.$ TPF $\mathrm{g}^{-1}$ soil $\left.\mathrm{h}^{-1}\right)$. The higher soil dehydrogenase enzyme activity in GRDF treatment might be associated with addition of nitrogen in GRDF treatment was through urea fertilizer. The urea fertilizer consist of both carbon and nitrogen which was source of energy to soil microorganisms and enhanced the microbial populations. The major source of soil dehydrogenase enzyme in soil is the lysis of microbial cell. These observations are in accordance with the observations of Kulkarni and Kale (2014).

The use of slow release nitrogenous fertilizers as $50 \%$ RDN-urea $+50 \%$ NCU was found significantly superior for soil dehydrogenase enzyme activity at 7, 21, 45 and 90 DAA $\left(1.34,1.47,1.61\right.$ and $1.50 \mu \mathrm{g} \mathrm{TPF}^{-1}$ soil $^{-1}$ respectively) over all the treatment of slow release nitrogen treatments except treatment GRDF. It was followed by 50\% RDN-urea + $50 \%$ SCU $(1.31,1.40,1.56$ and $1.49 \mu \mathrm{g}$ TPF $\mathrm{g}^{-1}$ soil $\mathrm{h}^{-1}$ respectively) and 50\% RDN-urea + $50 \%$ CDU $(1.27,1.36,1.54$ and $1.46 \mu \mathrm{g}$ TPF $\mathrm{g}^{-1}$ soil $\mathrm{h}^{-1}$ respectively). However, the treatment consist of nitrogen application only through CDU, NCU, SCU or their combinations in the proportion of 50:50 per cent were recorded less soil dehydrogenase enzyme activity. The nitrogen application for their slow release through 50\% RDN-urea and remaining 50\% RDN either through CDU, NCU or SCU were beneficial for periodical soil dehydrogenase enzyme activity (Perucci, 1992). In general, the slow release nitrogen treatment as $50 \%$ RDN-urea $+50 \%$ through CDU, NCU and SCU were beneficial for periodical soil dehydrogenase enzyme activity. But it was comparatively less than the treatment GRDF.

\section{Effect of Slow Release Nitrogenous Fertilizers on Soil Bacterial Population}

The availability of nitrogen in soil to the crops is in the form of $\mathrm{NH}_{4}{ }^{+}-\mathrm{N}$ or $\mathrm{NO}_{3}{ }^{-} \mathrm{N}$. However, the addition of nitrogen to crop through chemical fertilizer and organic manures consist of nitrogen in organic form. The plant has not its own mechanism to absorb the nitrogen in organic form. Therefore, the nitrogen added in organic form is to be transformed into the inorganic form either as ammonical $\left(\mathrm{NH}_{4}{ }^{+}-\mathrm{N}\right)$ or nitrate $\left(\mathrm{NO}_{3}{ }^{-}-\mathrm{N}\right)$ form for their utilization by the field crops. The transformation or conversion of organic nitrogen to ammonical and nitrate nitrogen are brought by the Nitrosomonas and Nitrobacter in soil. Hence, the population of these organisms in soil has vital importance as far as better use efficiency of nitrogen added either through chemical fertilizer or organic manure. 
Table.1 Initial chemical and biological properties of soil

\begin{tabular}{|c|c|c|}
\hline Sr. No. & Soil properties & Value \\
\hline I. & Physical properties & \\
\hline & Textural class & Clayey \\
\hline II. & Chemical properties & \\
\hline 1. & $\mathrm{pH}(1: 2.5)$ & 8.00 \\
\hline 2. & $\mathrm{EC}(\mathrm{dS} \mathrm{m}-1)$ & 0.19 \\
\hline 3. & Calcium carbonate $(\%)$ & 7.83 \\
\hline 4. & Organic carbon $(\%)$ & 0.43 \\
\hline 5. & Available $\mathrm{N}\left(\mathrm{kg} \mathrm{ha}^{-1}\right)$ & 158.30 \\
\hline 6. & Available $\mathrm{P}\left(\mathrm{kg} \mathrm{ha}^{-1}\right)$ & 15.00 \\
\hline 7. & Available K $\left(\mathrm{kg} \mathrm{ha}^{-1}\right)$ & 429.65 \\
\hline III. & Biological properties & \\
\hline 1. & Urease enzyme $\left(\mu \mathrm{g} \mathrm{NH}_{4}-\mathrm{N} \mathrm{g}^{-1}\right.$ of soil $\left.\mathrm{h}^{-1}\right)$ & 16.30 \\
\hline 2. & Dehydrogenase enzyme activity $\left(\mu \mathrm{g}\right.$ TPF $\mathrm{g}^{-1}$ soil $\left.^{-1}\right)$ & 0.86 \\
\hline 3. & Nitrosomonas count (cfu x $10^{3} \mathrm{~g}^{-1}$ soil) & 3.40 \\
\hline 4. & Nitrobacter count (cfu $\times 10^{3} \mathrm{~g}^{-1}$ soil) & 4.00 \\
\hline
\end{tabular}

Table.2 Observations recorded in laboratory experiment

\begin{tabular}{|c|l|c|c|}
\hline $\begin{array}{c}\text { Sr. } \\
\text { No. }\end{array}$ & Parameter & Observations & Stage of observation \\
\hline 1. & Enzyme activity & Urease and Dehydrogenase & $\begin{array}{c}\text { At 7, 21, 45, 90 days } \\
\text { after incubation }\end{array}$ \\
\hline 2. & Soil microbial count & $\begin{array}{c}\text { Nitrosomonas and } \\
\text { Nitrobacter }\end{array}$ & $\begin{array}{c}\text { At 7, 14, 21, 28 days } \\
\text { after incubation }\end{array}$ \\
\hline
\end{tabular}

Table.3 Effect of slow release nitrogenous fertilizers on soil urease enzyme activity under laboratory condition

\begin{tabular}{|c|c|c|c|c|c|}
\hline \multirow{2}{*}{$\begin{array}{l}\text { Tr. } \\
\text { No }\end{array}$} & \multirow[t]{2}{*}{ Treatment } & \multicolumn{4}{|c|}{ Urease enzyme activity $\left(\mu \mathrm{g} \mathrm{NH}_{4}-\mathrm{Ng}^{-1}\right.$ soil $\left.\mathrm{h}^{-1}\right)$} \\
\hline & & 7 DAA & 21DAA & 45 DAA & 90 DAA \\
\hline $\mathbf{T}_{1}$ & Control & 16.63 & 17.24 & 18.46 & 17.33 \\
\hline $\mathbf{T}_{2}$ & GRDF & 32.73 & 34.83 & 37.89 & 35.79 \\
\hline $\mathbf{T}_{3}$ & $\mathrm{RDN}-\mathrm{CDU}$ & 22.66 & 24.59 & 25.90 & 26.60 \\
\hline $\mathbf{T}_{4}$ & RDN-NCU & 27.39 & 28.79 & 30.10 & 31.50 \\
\hline $\mathbf{T}_{5}$ & RDN-SCU & 28.18 & 29.93 & 30.80 & 32.11 \\
\hline $\mathbf{T}_{6}$ & $50 \%$ RDN - Urea + $50 \% \mathrm{NCU}$ & 30.98 & 32.38 & 33.34 & 34.21 \\
\hline $\mathbf{T}_{7}$ & $50 \%$ RDN - Urea + $50 \% \mathrm{CDU}$ & 30.01 & 31.59 & 32.64 & 33.25 \\
\hline $\mathbf{T}_{8}$ & $50 \%$ RDN - Urea + $50 \%$ SCU & 29.14 & 30.45 & 32.46 & 32.55 \\
\hline $\mathbf{T}_{9}$ & $50 \% \mathrm{RDN}-\mathrm{NCU}+50 \% \mathrm{CDU}$ & 25.20 & 26.69 & 28.09 & 29.14 \\
\hline $\mathbf{T}_{10}$ & $50 \% \mathrm{RDN}-\mathrm{NCU}+50 \% \mathrm{SCU}$ & 26.16 & 27.56 & 29.23 & 30.71 \\
\hline \multirow[t]{4}{*}{$\mathbf{T}_{11}$} & $50 \% \mathrm{RDN}-\mathrm{CDU}+50 \% \mathrm{SCU}$ & 24.24 & 25.81 & 27.04 & 28.53 \\
\hline & Initial & \multicolumn{4}{|c|}{16.30} \\
\hline & S.Em \pm & 0.19 & 0.24 & 0.32 & 0.33 \\
\hline & CD at $5 \%$ & 0.59 & 0.76 & 1.00 & 1.03 \\
\hline
\end{tabular}


Table.4 Effect of slow release nitrogenous fertilizers on soil dehydrogenase enzyme activity under laboratory condition

\begin{tabular}{|c|c|c|c|c|c|}
\hline \multirow{2}{*}{$\begin{array}{l}\text { Tr. } \\
\text { No }\end{array}$} & \multirow[t]{2}{*}{ Treatment } & \multicolumn{4}{|c|}{ Dehydrogenase $\left(\mu \mathrm{g}\right.$ TPF $\mathrm{g}^{-1}$ soil $\left.^{-1}\right)$} \\
\hline & & 7 DAA & 21 DAA & 45 DAA & 90 DAA \\
\hline $\mathbf{T}_{1}$ & Control & 0.92 & 1.05 & 1.14 & 1.11 \\
\hline $\mathbf{T}_{2}$ & GRDF & 1.41 & 1.55 & 1.69 & 1.56 \\
\hline $\mathbf{T}_{\mathbf{3}}$ & RDN-CDU & 1.11 & 1.21 & 1.40 & 1.32 \\
\hline $\mathbf{T}_{4}$ & RDN-NCU & 1.25 & 1.35 & 1.51 & 1.43 \\
\hline $\mathbf{T}_{5}$ & RDN-SCU & 1.19 & 1.28 & 1.47 & 1.40 \\
\hline $\mathbf{T}_{6}$ & $50 \%$ RDN - Urea + $50 \%$ NCU & 1.34 & 1.47 & 1.61 & 1.50 \\
\hline $\mathbf{T}_{7}$ & $50 \%$ RDN - Urea + $50 \%$ CDU & 1.27 & 1.36 & 1.54 & 1.46 \\
\hline $\mathbf{T}_{8}$ & $50 \%$ RDN - Urea + $50 \%$ SCU & 1.31 & 1.40 & 1.56 & 1.49 \\
\hline $\mathbf{T}_{9}$ & $50 \% \mathrm{RDN}-\mathrm{NCU}+50 \% \mathrm{CDU}$ & 1.18 & 1.26 & 1.44 & 1.37 \\
\hline $\mathbf{T}_{10}$ & $50 \% \mathrm{RDN}-\mathrm{NCU}+50 \% \mathrm{SCU}$ & 1.21 & 1.32 & 1.48 & 1.42 \\
\hline \multirow[t]{4}{*}{$\mathbf{T}_{11}$} & $50 \% \mathrm{RDN}-\mathrm{CDU}+50 \% \mathrm{SCU}$ & 1.16 & 1.24 & 1.42 & 1.35 \\
\hline & Initial & \multicolumn{4}{|c|}{0.86} \\
\hline & S.Em. \pm & 0.017 & 0.011 & 0.014 & 0.017 \\
\hline & CD at $5 \%$ & 0.055 & 0.035 & 0.044 & 0.054 \\
\hline
\end{tabular}

Table.5 Effect of slow release nitrogenous fertilizers on Nitrosomonas population under laboratory condition

\begin{tabular}{|c|c|c|c|c|c|}
\hline \multirow{2}{*}{$\begin{array}{l}\text { Tr. } \\
\text { No }\end{array}$} & \multirow{2}{*}{ Treatment } & \multicolumn{4}{|c|}{ Nitrosomonas count (cfu $\times 10^{3} \mathrm{~g}^{-1}$ soil) } \\
\hline & & 7 DAA & 14 DAA & 21 DAA & 28 DAA \\
\hline $\mathbf{T}_{1}$ & Control & 4.90 & 5.20 & 5.65 & 5.90 \\
\hline $\mathbf{T}_{2}$ & GRDF & 6.35 & 6.80 & 7.20 & 7.70 \\
\hline $\mathbf{T}_{\mathbf{3}}$ & RDN-CDU & 6.00 & 6.30 & 7.00 & 7.33 \\
\hline $\mathbf{T}_{4}$ & RDN-NCU & 6.13 & 6.90 & 6.80 & 7.10 \\
\hline $\mathbf{T}_{5}$ & RDN-SCU & 6.30 & 6.50 & 6.55 & 7.02 \\
\hline $\mathbf{T}_{6}$ & $50 \%$ RDN - Urea + $50 \%$ NCU & 5.00 & 5.50 & 5.80 & 6.07 \\
\hline $\mathbf{T}_{7}$ & $50 \%$ RDN - Urea + $50 \%$ CDU & 5.40 & 5.60 & 6.00 & 6.30 \\
\hline $\mathbf{T}_{8}$ & $50 \%$ RDN - Urea + $50 \%$ SCU & 5.20 & 5.40 & 5.70 & 5.72 \\
\hline $\mathbf{T}_{9}$ & $50 \% \mathrm{RDN}-\mathrm{NCU}+50 \% \mathrm{CDU}$ & 5.70 & 5.90 & 6.30 & 6.50 \\
\hline $\mathbf{T}_{10}$ & $50 \% \mathrm{RDN}-\mathrm{NCU}+50 \% \mathrm{SCU}$ & 5.90 & 6.20 & 6.40 & 6.75 \\
\hline \multirow[t]{4}{*}{$\mathbf{T}_{11}$} & $50 \% \mathrm{RDN}-\mathrm{CDU}+50 \% \mathrm{SCU}$ & 5.30 & 5.60 & 5.90 & 6.10 \\
\hline & Initial & \multicolumn{4}{|c|}{3.40} \\
\hline & S.Em. \pm & 0.09 & 0.25 & 0.07 & 0.08 \\
\hline & CD at $5 \%$ & 0.29 & 0.78 & 0.23 & 0.27 \\
\hline
\end{tabular}


Table.6 Effect of slow release nitrogenous fertilizers on Nitrobacter population under laboratory condition

\begin{tabular}{|c|c|c|c|c|c|}
\hline \multirow{2}{*}{$\begin{array}{l}\text { Tr. } \\
\text { No }\end{array}$} & \multirow[t]{2}{*}{ Treatment } & \multicolumn{4}{|c|}{ Nitrobacter count (cfu $\times 10^{3} \mathrm{~g}^{-1}$ soil) } \\
\hline & & 7 DAA & 14 DAA & 21 DAA & 28 DAA \\
\hline $\mathbf{T}_{1}$ & Control & 2.05 & 2.35 & 2.45 & 2.70 \\
\hline $\mathbf{T}_{2}$ & GRDF & 2.30 & 2.87 & 2.75 & 3.10 \\
\hline $\mathbf{T}_{\mathbf{3}}$ & RDN-CDU & 4.20 & 4.85 & 4.40 & 4.10 \\
\hline $\mathbf{T}_{4}$ & RDN-NCU & 2.65 & 4.67 & 2.40 & 2.90 \\
\hline $\mathbf{T}_{5}$ & RDN-SCU & 3.40 & 3.00 & 4.40 & 5.30 \\
\hline $\mathbf{T}_{6}$ & $\begin{array}{l}50 \% \text { RDN - Urea + } 50 \% \\
\text { NCU }\end{array}$ & 3.63 & 2.95 & 3.10 & 4.10 \\
\hline $\mathbf{T}_{7}$ & $\begin{array}{l}50 \% \text { RDN - Urea + } 50 \% \\
\text { CDU }\end{array}$ & 3.87 & 4.10 & 3.40 & 4.80 \\
\hline $\mathbf{T}_{\mathbf{8}}$ & $\begin{array}{l}50 \% \text { RDN - Urea + } 50 \% \\
\text { SCU }\end{array}$ & 1.60 & 2.75 & 3.90 & 5.10 \\
\hline $\mathbf{T}_{9}$ & $\begin{array}{l}50 \% \mathrm{RDN}-\mathrm{NCU}+50 \% \\
\mathrm{CDU}\end{array}$ & 2.50 & 2.60 & 4.30 & 3.90 \\
\hline $\mathbf{T}_{10}$ & $\begin{array}{l}50 \% \mathrm{RDN}-\mathrm{NCU}+50 \% \\
\text { SCU }\end{array}$ & 1.90 & 2.80 & 3.80 & 3.25 \\
\hline \multirow[t]{4}{*}{$\mathbf{T}_{11}$} & $\begin{array}{l}50 \% \mathrm{RDN}-\mathrm{CDU}+50 \% \\
\text { SCU }\end{array}$ & 1.70 & 2.50 & 4.00 & 4.75 \\
\hline & Initial & \multicolumn{4}{|c|}{4.00} \\
\hline & S.Em. \pm & 0.10 & 0.15 & 0.21 & 0.14 \\
\hline & CD at $5 \%$ & 0.31 & 0.49 & 0.65 & 0.46 \\
\hline
\end{tabular}

Fig.1 Effect of slow release nitrogenous fertilizers on soil urease enzyme activity under laboratory condition

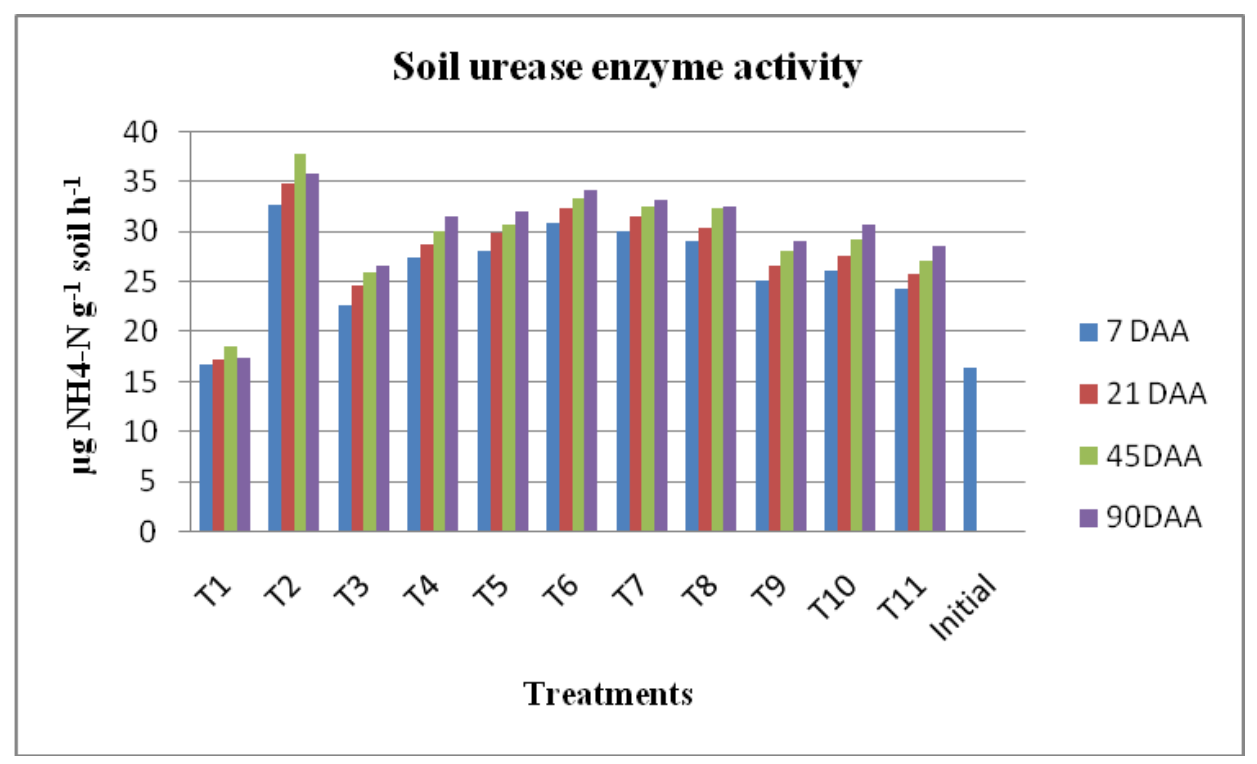


Fig.2 Effect of slow release nitrogenous fertilizers on soil dehydrogenase enzyme activity under laboratory condition

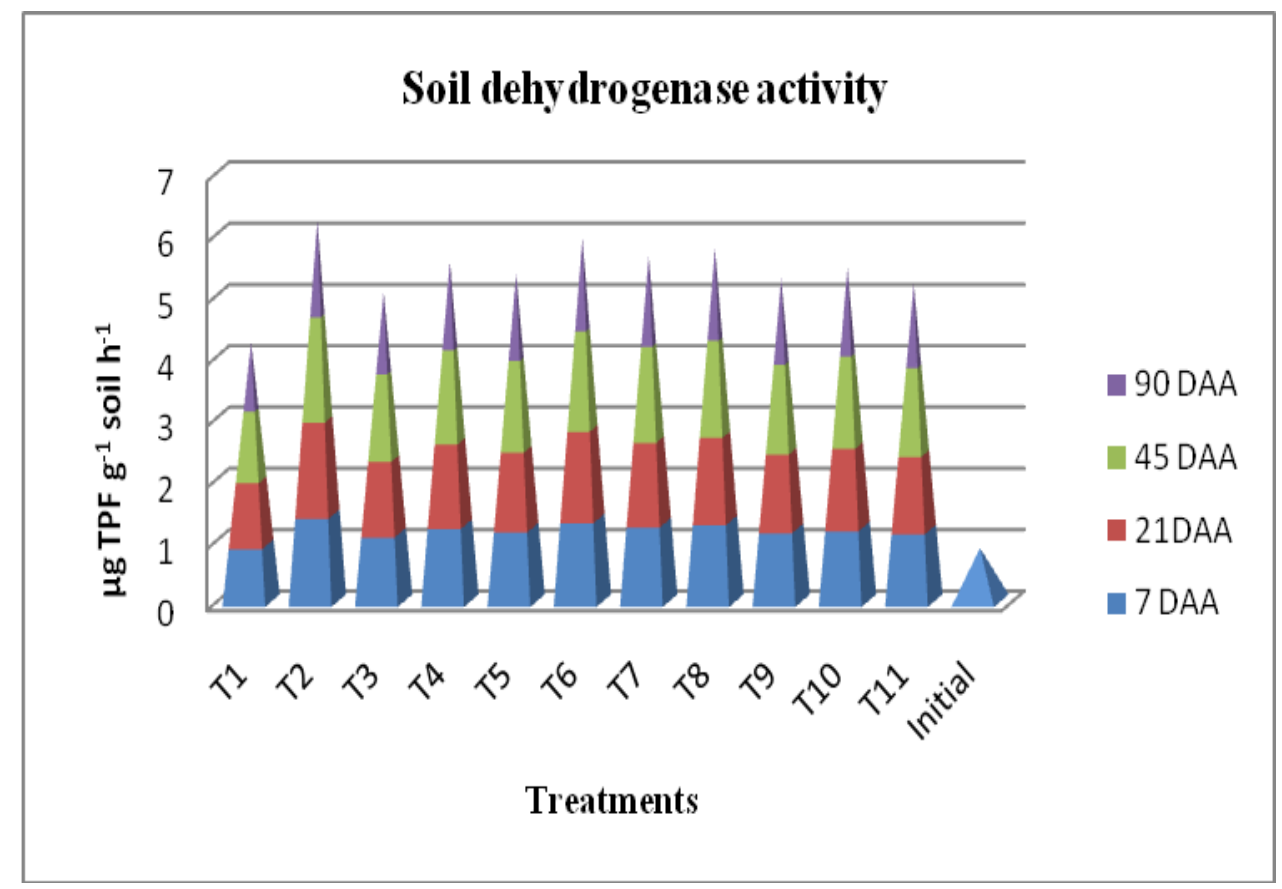

Fig.3 Effect of slow release nitrogenous fertilizers on soil Nitrosomonas population under laboratory condition

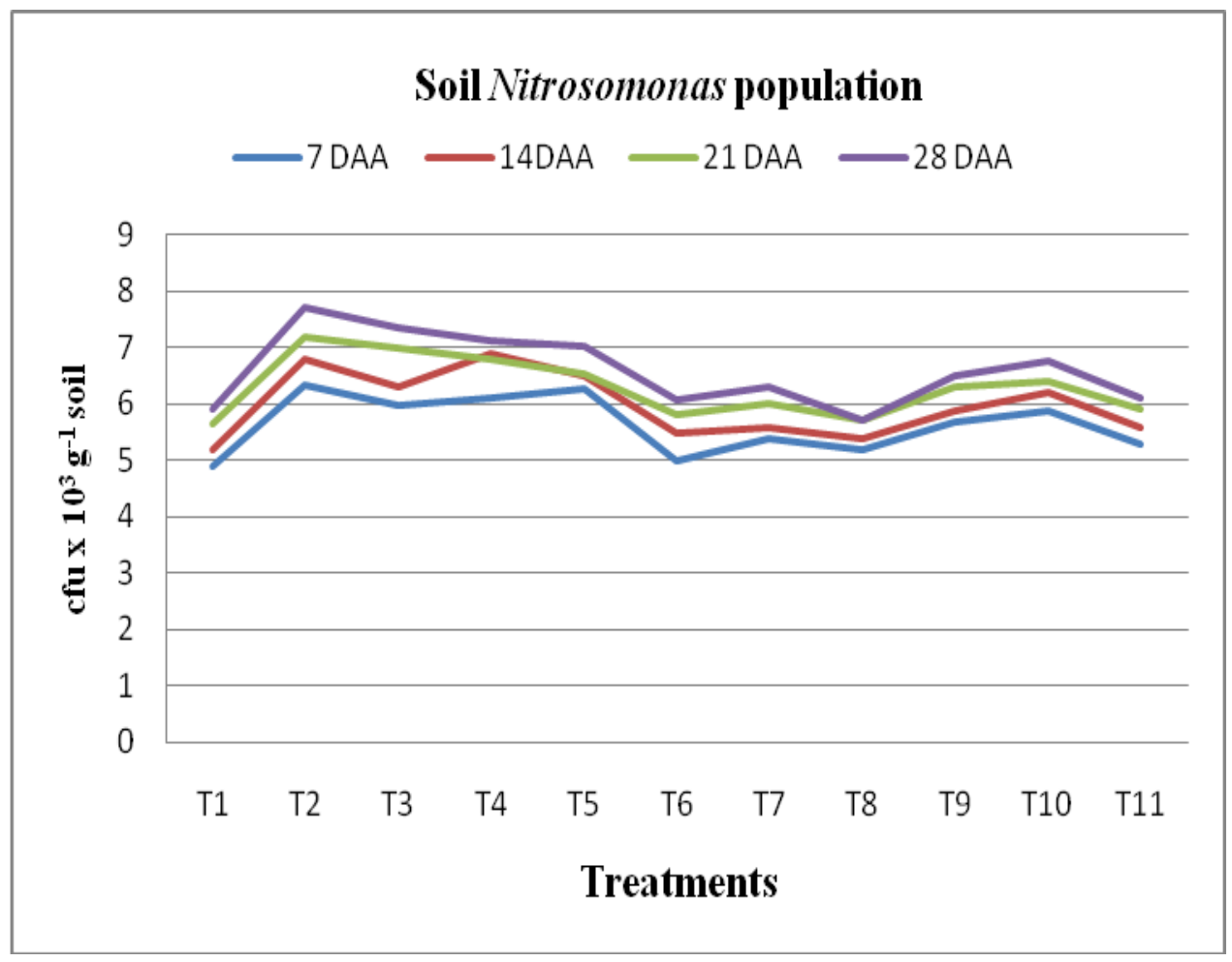


Fig.4 Effect of slow release nitrogenous fertilizers on soil Nitrobacter population under laboratory condition

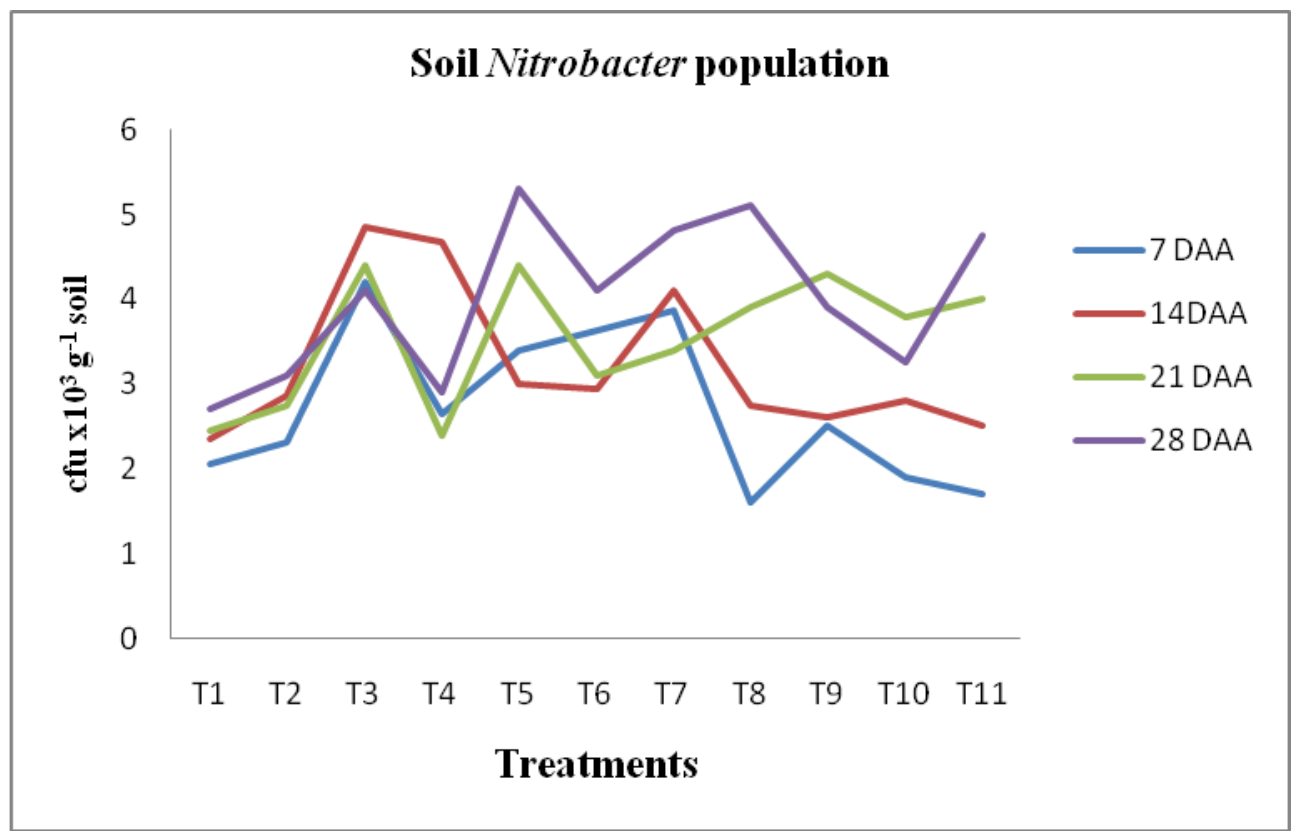

\section{Nitrosomonas population}

The periodical population of Nitrosomonas in soil as influenced by slow release nitrogen treatments is reported in Table 5 and Figure 3. The treatment GRDF significantly recorded the higher population of Nitrosomonas at all the period of incubation. However, it was statistically on par with treatment RDN-SCU, NCU and CDU at 7 DAA $(6.30,6.13$ and 6.00 cfu $\times 10^{3} \mathrm{~g}^{-1}$ soil respectively) and 14 DAA $\left(6.50,6.90\right.$ and 6.30 cfu $x \quad 10^{3} \mathrm{~g}^{-1}$ soil respectively). The population of Nitrosomonas was numerically less in treatment 50\% RDN-urea + 50\% RDN either through CDU, NCU and SCU and numerically higher in treatment $50 \% \mathrm{RDN}$ $\mathrm{NCU}+50 \% \mathrm{CDU}, 50 \% \mathrm{RDN}-\mathrm{NCU}+50 \%$ SCU and 50\% RDN-CDU $+50 \%$ SCU at all the periods of incubation but less than the treatment GRDF and RDN through CDU, NCU and SCU respectively. This might be associated with the use of organics as NCU, CDU and SCU as source of nitrogen to crops were consist of more amount of carbon and comparatively less amount of nitrogen, both the elements are used by the microorganism as source of their energy. It was reflected in higher Nitrosomonas population in soil (Santhi et al., 1986).

\section{Nitrobacter population}

The population of Nitrobacter in soil was significantly influenced by the slow release nitrogen treatment (Table 6 and Figure 4). The population of Nitrobacter in soil was comparatively less than the population of Nitrosomonas. The use of CDU as slow release nitrogen treatment was found superior for Nitrobacter population at all the periods of incubation in treatment RDN-CDU (4.20, $4.85,4.40$ and $4.10 \mathrm{cfu} \times 10^{3} \mathrm{~g}^{-1}$ soil respectively). It was numerically followed by treatment 50\% RDN-urea + 50\% CDU (3.87, $4.10,3.40$ and $4.80 \mathrm{cfu} \times 10^{3} \mathrm{~g}^{-1}$ soil respectively). The results of Nitrobacter population revealed that in early incubation period at 7 DAA, use of NCU and SCU recorded less Nitrobacter population (2.65 
and $3.40 \mathrm{cfu} \times 10^{3} \mathrm{~g}^{-1}$ soil). Similarly, the treatment of $50 \%$ RDN-urea $+50 \%$ SCU, $50 \%$ RDN-NCU + 50\% CDU, 50\% RDN$\mathrm{NCU}+50 \%$ SCU and 50\% RDN-CDU + $50 \%$ SCU were recorded less Nitrobacter population $(1.60,2.50,1.90$ and $1.70 \mathrm{cfu} x$ $10^{3} \mathrm{~g}^{-1}$ soil respectively). However, it was increased with an advanced period of incubation and showed the similar trend to that of at 7 DAA. The reduced population of Nitrobacter might be associated with the insecticidal property of neem seed and sulphur in early stage. Whereas, over a period, these compound decomposed and increased Nitrobacter population at later stage. These observations are in accordance with the observations of Elnasikh et al., (2011)

The application of RDN-CDU significantly reduced soil urease and dehydrogenase enzyme activity up to 90 DAA in laboratory incubation study by 25 and 15 per cent respectively as compared to GRDF treatment.

Urea, Crotonylidene diurea (CDU), sulphur coated urea (SCU) and neem coated urea (NCU) increased Nitrosomonas population in soil. CDU as a slow release nitrogen fertilizer was found superior for inhibiting Nitrobacter population at all the periods of incubation.

\section{References}

Aon, M.A. and Colaneri, A.C. (2001) Temporal and spatial evolution of enzymatic activities and physicochemical properties in an agricultural soil. Applied Soil Ecology 18, 255-270.

Casida, L.E., Jr. Klein, D. and Santora, R. (1964) Soil dehydrogenase activity. Soil Science 98, 371-378.

Chang, E.H., Chung, R.S. and Tsai, Y.H. (2007) Effect of different application rates of organic fertilizers on soil enzyme activity and microbial population. Journal of Soil Science and Plant Nutrition 53, 132-140.

Dahiya, S., Usha, Jaiwal, P.K. and Singh, R.P. (2004) Efficient nitrogen assimilation and high productivity in rice (Oryza sativa L.) applied with organic matrix based slow release nitrogen fertilizers. Physiology and Molecular Biology of Plants 10, 83-92.

Elnasikh, M.H., Osman, A.G. and Sherif, A.M. (2011) Impact of neem seed cake on soil microflora and some soil properties. Journal of Science Technology 12(1), 144-150.

Halvorsun, H.O. and Ziegler, N.R. (1993) Application of statistics to problems in bacteriology. I.A. means of determining bacterial population by the dilution method. Journal of Bacteriology 25, 101-121.

Kissel, D.E., Cabrera, M.L. and Paramasivm, S. (2008) Ammonium, ammonia and urease actions in soils. In Nitrogen in Agricultural Systems. Agronomy Monograph No. 49. (Schepers, J.S. and Raun, W.R. eds.), ASA-CSSA-SSSA, Madision, WI, 101-156.

Kulkarni, P. and Kale R.D. (2014) Urease and alkaline phosphatase activities in organic amended soils. Indian Journal of Advances in Plant Research 1(2), 4346.

Perucci, P. (1992) Enzyme activity and microbial biomass in a field soil amended with munciple refuse. Biology and Fertility of Soils 14, 54-60.

Ross, D.J. (1971). Some factors influencing the estimation of dehydrogenase activities of some soils under pasture. Soil Biology \& Biochemistry 3, 97-110.

Santhi, S.R., Palaniappan, S.P. and Purushothaman, D. (1986) Influence of neem leaf on nitrification in low land rice soil. Plant and Soil 93, 133-135.

Sun, Jingjing, Zhu Mijia., Yang Xiaoqia., Zhang Chi and Yao Jun. (2015) 
Microbial urease activities and organic matter responses to nitrogen rate in cultivated soil. The Open Biotechnology Journal 9, 14-20.
Tabatabai, M.A. and Bremner, J.M. (1972) Assay of urease activity in soil. Soil Biology and Biochemistry 4, 479-487.

\section{How to cite this article:}

Priyanka B. Patil, A.D. Kadlag and Durgude, A.G. 2019. Influence of Slow Release Nitrogenous Fertilizers on Soil Enzyme Activity and Microbial Population under Laboratory Condition. Int.J.Curr.Microbiol.App.Sci. 8(07): 652-662. doi: https://doi.org/10.20546/ijcmas.2019.807.081 